$\mathrm{KD}$ is also a research fellow at the London School of Hygiene and Tropical Medicine, London.

Contributors and sources: All authors contributed to the initial idea, the study design, and data analysis. AR led the data collection in Russia, emailing semistructured questionnaires to directors of general practice training centres in Russia in 2002. DB analysed the data and produced the first and the final drafts, with inputs from KD, AR, and MMcK. MMcK also edited the manuscript. All authors contributed to the analysis and the writing and have approved the final manuscript.

Funding: The authors are members of the Health Systems Development Programme, which is funded by the UK Department for International Development (DFID). The DFID supports policies, programmes and projects to promote international development. DFID provides funds for this study as part of that objective, but the views and opinions expressed are not necessarily those of the DFID.

Competing interests: None declared.

Ethical approval: Not required.

1 Lember M. A policy of introducing a new contract and funding system of general practice in Estonia. Int J Health Plann Manage 2002;17:41-53.

2 Lovkyte L, Padaiga Z. Physician workforce reform in Lithuania: an inevitable transition. Cah Sociol Demogr Med 2001;41:347-68.

3 Reamy J, Gedik G. Health human resource reform in Tajikistan: part of a masterplan for change. Cah Sociol Demogr Med 2001;41:327-45.

4 Kersnik J. Determinants of customer satisfaction with the health care system, with the possibility to choose a personal physician and with a family doctor in a transition country. Health Policy 2001;57:155-64.

5 Earl-Slater A. Health-care reforms in the Czech Republic.J Manag Med 1996:10:13-22.

6 Ryan M, Stephen J. General practitioners and family doctors in the Russian Federation. Br J Gen Pract 1996;46:487-9.

Sheiman I. The development of market approaches in Russia. Healt Policy 1995;32(1-3):167-80.

8 Ministry of Health of Russian Federation. Decree \#237: On stepwise transition of outpatient services to general practice model. Moscow, 1992. www/techno.edu.ru/db/msg/7033.html (accessed 22 Jun 2005).

9 Government of Russian Federation. Basis of legislation on health protection in Russia. Moscow, 1993. www.doktor.ru/econom/law/patient/osn.htm (accessed 22 Jun 2005)
10 Koppel A, Meiesaar K, Valtonen H, Metsa A, Lember M. Evaluation of primary health care reform in Estonia. Soc Sci Med 2003;56:2461-6.

11 World Bank. Health, nutrition and population in Europe and Central Asia.A decade of experience: lessons learned, implications for the future. 2003. http://siteresources.worldbank.org/INTECAREGTOPHEANUT/ Resources/HNPinECA_Dec2003_Ch1.pdf (accessed 22 Jun 2005).

12 Sharbarova Z. Primary health care in the NIS: history and current situation. An overview. American Iinternational Health Alliance, 2001. wwwaiha.com/ resources/Html/zova.htm (accessed 22 Jun 2005).

13 McEuen M. The pilot process: case study on piloting complex health reforms in Kyrgyzstan. Abt Associates, 2004. (www.phrplus.org/Pubs/Tech036_ fin.pdf) (accessed 22 Jun 2005).

14 Abzalova R, Wickham C, Chukmaitov A, Rakhipbekov T. Reform of primary health care in Kazakhstan and the effects on primary health care worker motivation: the case of Zherkargan region. 1998 (major applied research 5 , 2005)

15 Orlova GG, Gadzhieva LSh, Kalininskaia AA. [The training of family physicians.] Ter Arkh 1992;64:114-6. (In Russian.)

16 Goskomstat. Population census of the Russian Federation. Moscow: Goskomstat, 2002. www.perepis2002.ru/index.html?id=11 (accessed 22 Jun 2005).

17 Tishuk EA, Shchepin VO. [Topical issues of the primary medical and sanitary care.] Probl Sotsialnoi Gig Istor Med 2003;2:28-30. (In Russian.)

18 Ministry of Health. Indicators of health and health care. MoH: Moscow, 2003.

19 Chernichovsky D, Potapchik E. Genuine federalism in the Russian health care system: changing roles of government. $J$ Health Polit Policy Law 1999;24:115-44

20 Sheaff R. An international comparison: the Leningrad experiment. In: Cook H, ed. The NHS-private sector interface. Longman: Harlow, 1990: $33-46$.

21 Curtis S, Petukhova N, Taket A. Health care reform in Russia: the example of St Petersburg. Soc Sci Med 1995;40:755-65.

22 Shchepin OP, Tregubov IuG, Rytvinskii SS, Parkhachev VF. [Integration activities of a central municipal hospital.] Probl Sotsialnoi Gig Istor Med 2001; Jan-Feb:11-3. (In Russian.)

23 Polluste K, Kalda R, Lember M. Evaluation of primary health care reform in Estonia from patients' perspective: acceptability and satisfaction. Croat Med J 2004;45:582-7.

24 Kersnik J. An evaluation of patient satisfaction with family practice care in Slovenia. Int J Qual Health Care 2000;12:143-7.

25 Boerma W. Profiles of general practice in Europe. An international study of variation in the tasks of general practitioners. Utrecht: Netherlands Institute for Health Services Research (NIVEL), 2003

\section{Don't give up hope}

In a recent visit to the intensive care unit I saw a 69 year old Hindu patient. His case was unusual in that he had been brought back to our hospital after active treatment had been declined by his family at an earlier presentation.

He had first visited the hospital 25 days previously for limb weakness and bladder and bowel incontinence associated with dizziness but no headache. He had no spinal injury, and the results from magnetic resonance imaging were normal. He was sent back home with conservative management-corticosteroid, multivitamins, and treatment for his concurrent illnesses of benign enlargement of the prostate and hypertension.

The patient then developed acute retention of urine, for which he was taken to another hospital and catheterised. He was admitted for 10 days, and during that time he developed absolute constipation, which was relieved with an enema. He was discharged back home.

At home he developed abdominal pain and distension, constipation, and reduced urine output, and was brought back to our hospital. His general condition was poor, and a provisional diagnosis of peritonitis secondary to bowel perforation was made. This was explained to his family, who were asked for permission to undertake a diagnostic laparotomy. The family, however, refused: they thought that he was approaching death and that he wouldn't benefit from further active treatment. Instead, they wanted to allow him to die at Pashupatinath temple. The doctors therefore simply inserted two abdominal drains under local anaesthetic, and about $50 \mathrm{ml}$ of fluid drained from each.

The patient was duly taken to Pashupatinath to await death in the vicinity of the great Hindu god Pashupati. During their wait, the family members felt that the patient showed some improvement and so brought him back to our hospital. This time they gave the high risk consent for emergency laparotomy. This revealed multiple jejunal diverticula and a large perforation in one of them. After resection and anastomosis, the patient's condition rapidly improved.

Many Hindus believe that dying at a holy site will secure a place in heaven, and strive to achieve this. However, this can create a dilemma as to when to go to the temple or shrine of choice, where there are unlikely to be any treatment facilities. It is very difficult for family members to make such a decision for a patient who is elderly with multiple illnesses. In my opinion, however, the question of when to die should be more important than choosing where to die. We should obviously respect patients' wishes, but it is equally important to teach them that they should give treatment a chance first. "Saas rahe samma aas" [Hope till the last breath] as a motivational Nepali proverb says.

Kaushal Raj Pandey medical student, Institute of Medicine, Kathmandu,Nepal (krpandey702@emailaccount.com) 